\title{
CAMPUR KODE DAN ALIH KODE PADA KOMUNIKASI SEHARI - HARI MASYARAKAT DI SEKITAR TAHURA BENGKULU TENGAH
}

\author{
Agita Misriani \\ Dosen Tadris bahasa Indonesia \\ Institut Agama Islam Negeri Curup \\ agita_misriani@yahoo.com
}

\begin{abstract}
Abstrak: Penelitian ini bertujuan mendeskripsikan campur kode dan alih kode berkomunikasi dalam aktivitas sehari - hari masyarakat Lembak di daerah Tahura dan penggunaan bahasa tersebut dalam aktivitas sehari - hari masyarakat Lembak di daerah Tahura. Ruang lingkup penelitian ini adalah aktivitas non formal.Partisipan dalam penelitian ini yakni, Remaja, dewasa serta orang tua, dengan pendidikan mulai dari yang tidak sekolah, SD, SMP, SMA, dan Perguruan Tinggi. Responden dalam penelitian ini memiliki pekerjaan yang berbeda mulai dari siswa, ibu rumah tangga, penjual makanan, dan petani. Penelitian ini mengacu pada teori yang dikemukakan oleh Chaer dan Agustina 1995:4), Appeal (dalam Suwito, 1983:5), Nababan (dalam Chaer dan Agustina, 2004: 3) tentang ilmu sosiolinguistik. Metode yang digunakan metode deskriptif kualitatif. Setelah melakukan penelitian, penulis menemukan data diantaranya, ada empat bahasa yang digunakan oleh masyarakat Lembak di Tahura untuk berkomunikasi,yaitu bahasa Lembak, bahasa Melayu Bengkulu, bahasa Rejang, dan bahasa Jawa. Penggunaan keempat bahasa tersebut sesuai dengan konteks dan partisipan. Akibat adanya bahasa lain selain bahasa Lembak, maka muncullah campur kode dan alih kode pada saat masyarakat berkomunikasi dalam aktivitas mereka sehari - hari.
\end{abstract}

\section{Kata kunci: Campur kode, Alih kode}

Abstract: This study aims to describe mixed code and code transfer communicating in the daily activities of the Lembak people in the Tahura area and the use of the Tahura area.The scope of this research is non formal activities. Partiipants in this study are, Adolescents, adult and parents, with education ranging from those who are not in school, high school and university. Respondents in this study had different jobs ranging from students, housewife, food sellers, and famers. This research refers to the theory put forward by (Chaer and Agustina 1995:4), Appeal (in Suwito, 1983:5), Nababan ( in Chaer and Agustina, 2004:3) about sociolinguistics. The method used is descriptive qualitative method. After conducting research, the authors found data including, the are four languages used by the Lembak people in Tahura Communicate, namely the Lembak language, Bengkulu Malay Language, Rejang language, an javanese. The use of these four languages is in accordance with the context and participants As a result of languages other than Lembak, code and code switching emerged when poeple communicated in their daily activities.

Keywords: Mixed Code, Transfer Code 


\section{PENDAHULUAN}

Sarana komunikasi yang paling penting pada masyarakat adalah bahasa. Oleh karena kedudukannya yang sangat penting, maka bahasa tidak akan pernah lepas dari kehidupan manusia dan selalu ada dalam setiap aktivitas dan kehidupannya. Pemakaian bahasa dalam komunikasi selain ditentukan oleh faktor - faktor linguistik juga ditentukan oleh faktor-faktor nonlinguistik atau luar bahasa, antara lain faktor sosial yang merupakan faktor yang berpengaruh dalam penggunaan bahasa. Pandangan demikian memang cukup beralasan karena pada dasarnya bahasa adalah bagian dari suatu sistem sosial.

Indonesia merupakan negara multietnis yang memiliki beratus-ratus bahasa daerah. Dengan adanya bermacam-macam bahasa daerah di Indonesia, menjadikan bahasa daerah menjadi salah satu penunjuk identitas suatu etnis. Walaupun memiliki bermacam-macam bahasa daerah, salah satu ciri yang menonjol dari identitas bangsa Indonesia yaitu adanya bahasa persatuan, bahasa Indonesia. Selain bahasa Indonesia, bahasa daerah juga memiliki peranan besar, selain sebagai ciri suatu etnis dan menunjukkan bahwa Indonesia memiliki berbagai macam bahasa, bahasa daerah juga merupakan bahasa keakraban dalam suatu masyarakat.

Bahasa Lembak merupakan bahasa daerah yang masih hidup dan berkembang di dalam masyarakat di Tahura sampai saat ini. Adapun wilayah penggunaan bahasa Lembak ini tersebar di beberapa tempat yakni, Kecamatan Kota Padang, Padang Ulak Tanding, Kepala Curup, desa Pagar Dewa, desa Sukarami, , desa Dusun Besar, Kelurahan Panorama, serta Kelurahan Jembatan Kecil.

Untuk berkomunikasi dalam kehidupan sehari - hari, salah satu bahasa yang digunakan masyarakat Lembak adalah bahasa Lembak. Bahasa Lembak ini digunakan sebagai alat penghubung untuk melancarkan aktivitas mereka. Bahasa Lembak tidak hanya digunakan di dalam lingkungan keluarga, misalnya percakapan antara orangtua dengan anak atau adik dengan kakak, namun juga digunakan di dalam lingkungan masyarakat yang lebih luas. Misalnya percakapan dengan bahasa Lembak dapat digunakan di warung, di masjid, di sawah, di kebun, bahkan di lingkungan sekolah. Sebagai contoh, bahasa Lembak di gunakan dalam lingkungan keluarga, percakapan yang sederhana antara seorang ibu dengan anaknya. Suatu pagi sang ibu bertanya kepada anaknya, mengapa tidak berangkat ke kantor. Percakapan dengan bahasa Lembak yang digunakan oleh sang ibu yang bertanya kepada anaknya yakni:

I $\quad$ :"Col belan nga arai ikak, nak?" ( Tidak pergi ke kantor hari ini, nak?)

A :"Col Mak. Mulai bilai ikak libur, arai kamis baru masuk belan agi" (Tidak Bu. Mulai hari ini libur, hari kamis baru masuk kantor lagi).

Percakapan di atas merupakan percakapan singkat dengan menggunakan bahasa Lembak untuk berkomunikasi antara anggota keluarga. Pemilihan bahasa dengan melihat konteks, sangat diperlukan saat berkomunikasi di dalam masyarakat di daerah Tahura, karena 
dengan menggunakan bahasa yang tepat pada saat berkomunikasi dengan lawan tutur, maka komunikasi akan berjalan degan lancar.

Akibat adanya beberapa bahasa yang terdapat di dalam masyarakat di daerah Tahura, maka muncullah alih kode yang terjadi pada saat berkomunikasi dalam masyarakat di Tahura. Contohnya pada saat si A berkomunikasi dengan si B di warung, masing - masing mereka merupakan penutur bahasa Lembak yang menguasai bahasa Melayu Bengkulu, namun ketika si $\mathrm{C}$ datang, yang merupakan penutur bahasa Rejang dan menguasai bahasa Melayu Bengkulu juga maka, mereka akan menggunakan bahasa Melayu Bengkulu untuk komunikasi selanjutnya.

A: La turun harge cabe kini cik? ( Sudah turun harga cabai sekarang cik)

B: Au. Ku beli arai kamis ikak, sekilo la 50 ribu. kalu dak turun harge cabe tu menanggung nian, beli semate dak cukup nyambal sekali. (Iya. Saya beli hari kamis kemarin, 1 kilo 50 ribu. kalau harga cabai tidak turun, susahnya minta ampun, beli 1 ons tidak cukup untuk membuat sambal).

A: Au nian Cik, semate tu dikit nian. Ku ade beli pas yang cabe masih harge 60, pas balik rase 2 keilangan pitisku. (Iya betul cik, 1 ons itu dikit sekali, saya ada membeli cabai sewaktu harga cabai masih 60 ribu, waktu pulang saya rasa - rasa kehilangan uang).

Lalu datang si C yang merupakan penutur bahasa Rejang.

C: Apo yang diomongkan tu Cik? Seru nian aku tengok. (Apa yang dibicarakan Cik? saya lihat seru sekali).

B: Ngomongkan hargo cabe, kemeren - kemaren hargonya mahal nian, tapi kini la turun la dikit hargo cabenyo. (Membicarakan harga cabai, kemarin - kemarin mahal sekali, tapi sekarang sudah turun harga cabainya walaupun sedkit).

C: Ambo ado jugo beli cabe hargo 60 ribu kemarin.(Saya ada juga beli cabai harga 60 ribu kemarin).

A: Kalu aku raso - raso keilangan duit balik dari pasar beli cabe. (kalau saya rasa rasa kehilangan uang pulang dari pasar beli cabai).

Percakapan dalam tuturan tersebut, terjadinya alih kode dari bahasa Lembak ke bahasa Melayu Bengkulu, ini terjadi karena partisipan yang berbeda dan tidak mengerti bahasa Lembak, sehingga penutur bahasa Lembak harus menggunakan bahasa Melayu Bengkulu untuk melanjutkan komunikasi.

Saat melakukan aktivitas, masyarakat di daerah Tahura tidak hanya menggunakan bahasa Lembak saja, namun terdapat juga bahasa lain. Bahasa - bahasa tersebut yaitu bahasa Melayu Bengkulu, bahasa Rejang, dan bahasa Jawa. 
Dengan adanya mobilitas penduduk ke daerah ini, yang memiliki perbedaan etnis suku, maka lambat laun akan terjadi kontak bahasa di antara kedua etnis, misalnya etnis Rejang dan Lembak, ini muncul akibat adanya komunikasi yang terjadi antara keduanya. Selain itu, daerah ini termasuk daerah strategis, yang merupakan jalur alternatif yang menghubungkan dengan daerah lain misalnya ke Pondok Kubang, Batu Raja, Plajau lalu akan menuju ke daerah Taba Penanjung (BENTENG). Maka, secara tidak langsung terkadang orang yang melewati daerah ini mampir sejenak, dan akan terjadi komunikasi antara beberapa orang yang berasal dari daerah - daerah tersebut. Bila secara terus menerus daerah ini dilalui sebagai jalur alternatif maka, akan terjadi percampuran kosakata bahkan akan terjadi penggunaan bahasa yang bercampur kode.

Berdasarkan kondisi masyarakat yang beragam, yang tidak hanya terdiri dari penduduk asli Lembak, tetapi juga penduduk pendatang, memungkinkan terjadinya alih kode dan campur kode ketika mereka berkomunikasi. Sebagai contoh terjadinya campur kode antara bahasa Lembak dan Melayu Bengkulu, antara si A dan si B. Si A adalah pemilik warung yang merupakan penutur asli bahasa Lembak, sedangkan si B yang merupakan penutur Melayu Bengkulu yang sedang mencari ikan teri, yang juga menguasai bahasa Lembak.

A: " Ndak beli ape nga?" (Mau beli apa kamu?).

B: " Ade kan teri col? Aku la ngulu ncari ke warung Do Hen, col ade pule".

(Ada ikan teri tidak? Saya sudah ke hulu mencari ikan teri ke warungnya kakak Hen, namun tidak ada).

A: "Ado yuk, nga ndak berape?"( ada yuk, kamu mau berapa?)"

B: " Seribu ajo. Banyak nian dilek col juge ade yangmakannyo.(seribu saja. banyak sekali nanti tidak juga ada yang makannya )

Dari percakapan di atas, maka terlihat adanya campur kode yang digunakan saat penutur dan lawan tutur berkomunikasi di warung si penutur. Kata ado dalam bahasa Lembaknya adesedangkan nian bahasa Lembaknya ige serta kata makannyo dalam bahasa Lembak yakni makannye.

Daerah Tahura juga terkenal dengan kebun sawit serta persawahan, yang pemiliknya bukan penduduk asli masyarakat Lembak dan tidak berdomisili di daerah tersebut. Pada saat si pemilik sawah atau kebun sawit tersebut datang untuk melihat kebun sawit atau sawahnya, yang dikerjakan oleh penduduk daerah Tahura mulai dari menanam, memberi pupuk serta memanennya. Sehingga, akan terjalin sebuah komunikasi antara si pemilik kebun atau sawah yang bukan merupakan penduduk asli Lembak, dengan penduduk asli Lembak yang sehari harinya menggunakan bahasa Lembak untuk berkomunikasi. Akibatnya kontak bahasa, antara bahasa pemilik kebun (pendatang) dengan bahasa penduduk asli Lembak akan terjadi percampuran kosakata melalui interaksi mereka yang mengakibatkan munculnya campur kode. 
Penelitian ini akan membahas mengenai, "Penggunaaan Bahasa dalam Aktivitas Sehari - hari Masyarakat Lembak di Tahura". Adapun bahasa yang biasa masyarakat di daerah Tahura ini gunakan selain bahasa Lembak adalah bahasa Melayu Bengkulu, bahasa Rejang, dan juga bahasa Jawa. Bahasa - bahasa ini digunakan pada saat mereka berinteraksi dengan orang lain yang berada di sekitar mereka.

Masyarakat di daerah Tahura biasanya menggunakan bahasa Lembak untuk berinteraksi dengan sesama mereka yang menguasai bahasa Lembak. Namun, ada juga masyarakat tutur bahasa Lembak yang telah menguasai bahasa Rejang, Jawa dan Melayu Bengkulu, akibat seringnya berinteraksi dengan masyarakat pendatang. Begitu juga sebaliknya, masyarakat pendatang juga telah menguasai bahasa Lembak sehingga, saat berkomunikasi terjadi sebuah keakraban antara si penutur dan lawan tutur dalam suatu pembicaraan, misalnya antara bahasa Lembak dan Melayu Bengkulu.

Berdasarkan deskripsi di atas, maka penelitian mengenai penggunaan bahasa dalam aktivitas sehari - hari masyarakat Lembak ini, sangat menarik untuk di jadikan sebagai bahan penelitian sosiolinguistik. Sebelumnya, ada juga peneliti yang telah mencoba mengkaji bahasa dari sudut pandang sosiolinguistik, misalnya saja penelitian yang dilakukan oleh Desi Mediana Fitri mengenai alih kode dan campur kode dalam bahasa Lembak. Lalu, Bilingualisme dalam komunikasi Lisan masyarakat Lembak dikecamatan Kota Padang Kabupaten Rejang Lebong, merupakan skripsi mahasiswi Bahasa Indonesia tahun 2004 yakni Eli Minarti. Itu semua menunjukkan bahwa bahasa Lembak berpotensi untuk diteliti lebih jauh, untuk menunjukkan bahwa bahasa daerah, terutama bahasa Lembak masih dilestarikan oleh masyarakat sebagai salah satu ciri kebudayaan mereka. Penelitian ini, berbeda dengan penelitian - penelitian sebelumnya. Jika Desi mengkaji bahasa daerah Lembak dengan Melayu Bengkulu serta Melayu Palembang, dan Eli meneliti Bahasa Lembak dengan Bahasa Indonesia, maka penelitian ini mencakup Bahasa Lembak, Rejang, Jawa, Melayu Bengkulu.

\section{METODE PENELITIAN}

Metode yang digunakan dalam penelitian ini adalah metode deskriptif kualitatif. Menurut Fatimah (2006: 9) Penelitian deskriptif kualitatif merupakan penelitian yang bertujuan membuat deskripsi, maksudnya membuat gambaran, lukisan secara sistematis, faktual dan akurat mengenai data, serta hubungan fenomena - fenomena yang di teliti.

Penelitian ini berusaha untuk mendeskripsikan dan memberi gambaran mengenai masalah kebahasaan yang ada di dalam masyarakat di daerah Tahura. Bahasa apa saja yang digunakan pada saat kondisi nonformal, serta saat berkomunikasi dengan lawan bicara yang berbeda dari usianya, pendidikan serta topik pembicaraan yang dibicarakan. Dengan menggunakan metode ini, diharapkan mendapat data yang objektif berdasarkan fakta yang benar - benar ada di dalam masyarakat. Lokasi penelitian ini adalah didaerah Tahura (Desa Dusun Baru I, II, Tanjung Terdana). Data yang dikumpulkan bukanlah berbentuk angka, namun berupa kata - kata atau gambaran tentang suatu bahasa. Data yang dikumpulkan 
mungkin berasal dari naskah, wawancara, catatan, dokumen pribadi (Fatimah, 2006:16). Data dalam penelitian ini adalah aktivitas masyarakat di daerah Tahura, yang berhubungan dengan komunikasi mereka sehari - hari.

Instrumen utama dalam penelitian ini adalah peneliti sendiri, dan didukung dengan instrumen lain dalam pengumpulan data penelitian, misalnya dengan menggunakan lembar observasi dan panduan wawancara sebagai instrumen pendukung. Teknik yang digunakan untuk memeriksa keabsahan data dalam penelitian ini adalah teknik triangulasi.

\section{HASIL PENELITIAN DAN PEMBAHASAN}

\section{Bahasa yang digunakan masyarakat Tahura dalam berkomunikasi}

Masyarakat di Tahura, mayoritas merupakan penutur bahasa Lembak. Bahasa Lembak dalam masyarakat Lembak tidak bisa berkembang sendiri, artinya terdapat bahasa lain juga yang hidup di dalam masyarakat tersebut. Setiap bahasa memiliki fungsi masing masing dalam kehidupan masyarakat Lembak di Tahura. Dengan demikian, terbentuk suatu kondisi yang mengharuskan masyarakat mampu memilih bahasa apa yang digunakan untuk suatu percakapan agar mitra tuturnya memahami apa yang sedang dibicarakan.

Lalu aktivitas penduduk yang berkomunikasi dengan penduduk pendatang yang membawa bahasa daerah mereka masing - masing. Berdasarkan hasil penelitian yang telah dilakukan dapat diketahui bahwa, masyarakat di daerah Tahura merupakan masyarakat yang bilingual, artinya mereka memiliki kemampuan atau sanggup untuk menggunakan dua bahasa atau lebih. Bahasa - bahasa itu adalah bahasa Lembak, bahasa Rejang, bahasa Jawa, dan bahasa Melayu Bengkulu. Keadaan semacam ini menunjang terjadinya peristiwa campur kode dan alih kode dalam tindak tutur sehari - hari masyarakat di daerah Tahura.

Hal ini, sesuai dengan yang dikemukakan oleh bapak Muslim pada saat di wawancarai. Ia mengatakan bahwa masyarakat di daerah Tahura ini, menggunakan empat bahasa dalam aktivitas berkomunikasi sehari - hari. Adapun bahasa - bahasa tersebut yakni, bahasa Lembak, Melayu Bengkulu, Rejang dan Jawa.

Beberapa bahasa yang digunakan dalam masyarakat di daerah Tahura ini, digunakan sebagai sarana komunikasi pada situasi yang berbeda- beda. Masyarakat Lembak menggunakan beberapa bahasa tersebut seperti pada situasi nonformal misalnya, saat mereka berada di mesin tumbuk padi, di warung, di rumah, di sawah ataupun di tempat salah satu warga yang mengadakan hajatan.

Komunikasi pada setting A ini menggunakan bahasa Lembak, komunikasi terjadi di suatu mesin tumbuk padi di desa Dusun Baru I, pada pukul 14.35 WIB milik bapak Muslim (AA) yang usianya sekitar 57 tahun dengan profesi petani sawit serta pendidikan terakhirnya SD. Komunikasi ini terjadi antara pemilik mesin dengan seorang warga yang bernama Taher 
(AB) yang berusia 25 tahun dengan profesi buruh tani dengan pendidikan terakhir SD. Keduanya merupakan penduduk asli Lembak yang merupakan penutur bahasa Lembak. Topik pembicaraan dalam setting ini yaitu "menumbuk padi", perhatikan contoh berikut:

1. $\mathrm{AB}$ : Idup mesin pakwo?

(Hidup mesin pakwo?)

2. AA : Kalu col rusak ,idup terus mesin di sikak. Banyak ndak nutuk?

(Kalau tidak rusak, hidup terus mesin di sini. Banyak mau numbuk?

3. AB : Col pulə banyak Pakwo, Cuma duə karung. Pakwo surang nak mesin? manə tubə dang en?

(Tidak juga banyak Pakwo, Cuma 2 karung. Pakwo sendiri di mesin? Kemana Kak En?

4. AA : En lagi ke sawah, di sawah nyə banyak nian burung. Abis padi dimakannnyə kamu kemaren dak banyak burung di sawah?

(En lagi ke sawah, di sawahnya banyak sekali burung. Habis padi

dimakannya. Tidak banyak burung di sawah kamu kemarin?).

5. AB : Banyak jugə Pakwo. Ku temalam terus nak sawah, jingok la Pakwo cuma dapat duə karung ikak la adə padi.

(Banyak juga pakwo. Saya menginap di sawah terus, Pakwo bisa lihat Cuma dapat 2 karung padi).

Komunikasi pada setting A menunjukkan bahwa, partisipan yang terlibat percakapan tersebut memiliki latar belakang usia, profesi yang berbeda.

Dari percakapan di atas terlihat bahwa partisipan, khususnya penutur dan lawan tutur yakni bapak Muslim dan Madan menggunakan bahasa Lembak tanpa adanya unsur bahasa lain saat mereka berkomunikasi, karena keduanya memang merupakan penutur bahasa Lembak asli.

Selain bahasa Lembak, di Tahura juga ada penutur bahasa Rejang. Komunikasi dengan bahasa Rejang ini terlihat ketika seorang ibu yang bernama Rahuna (BA) yang berusia 51 tahun dengan profesi ibu rumah tangga dan pendidikan akhir SD, sedang santai pada saat sore hari sekitar pukul 16.40 WIB di teras rumah bersama anak laki - lakinya yang bernama Nadi (BB) berusia tahun 27 tahun yang bekerja sebagai buruh dengan pendidikan terakhir SMP. Mereka adalah penutur bahasa Rejang asli yang berdomisili di Tahura. Topik dalam percakapan tersebut mengenai"kepergian mereka ke pernikahan saudaranya yang akan dilaksanakan pada waktu dekat".

BA : Tinga lemo bilei igei au Med, anak Cik Bas nu nikeah?

( Tinggal lima hari lagi ya med, anak cik Bas mu menikah?)

BB : Amen ku coa saleah, au mak. Duei bilei igei ba ite aleu mei mini, memen ku 
gilak kerjo kileah coa nam teninga.

(Kalau saya tidak salah, iya bu. Dua hari lagi saja kita pergi ke sana, besok saya masih kerja karena tidak bisa ditinggalkan).

BA : Mak memen aleu mai umeah cik nu. Bapak udi bi sebilei baru pacak aleu mini, memen gilak mai saweah, ko serpak bapak be, kunyeu mak mageh Reka be aleu ne memen ho.

( Ibu besok pergi ke rumah cik mu. Bapak kalian lusa baru bisa pergi ke sana, Besok masih mau pergi ke sawah, kau serempak bapak saja, biar ibu dengan Reka saja besok pergi).

BB : Hakweng memen mak aleu ine bi kakbea? karno ku lak makei motor kileah motorku gi nak bekel.

( Ibu perginya pagi besok atau sor? Karena saya mau pakai motor dulu, motor saya masih di bengkel).

BA : Jam kedeu ko belek? Amen pacak coa mak aleu bi kakbeah, be ujen ipo hoah kulo.

(Jam berapa kamu pulang? Kalau bisa ibu tidak mau pergi sore, nanti hujan mana jauh lag).

BB : Kakbilei ku bibelek. Tinga umeah ite be mak, amen ite aleu kehte?

(Siang saya pulang. Tinggal rumah kita nanti bu, kalau kita pergi semua?)

BA : Au. Tun depeah yo ade kemleah - kemleah umeah.

( Iya . Orang sebelah ada untuk melihat - lihat rumah).

BB : Ku lak aleu kemleah motor ku kileah mak nak bekel, api teu bi udem.

( Saya mau pergi melihat motor saya dulu bu di bengkel, siapa tahu sudah Selesai).

BA : Atei - atei, nak. rami nien dalen bilei yo ba.

( Hati - hati, nak. Jalan ramai sekali hari ini).

Percakapan di atas, merupakan percakapan antara seorang ibu dan anaknya dengan menggunakan bahasa Rejang. Tidak ada unsur bahasa lain yang muncul di dalam percakapan tersebut. 
Komunikasi dengan menggunakan bahasa Jawa pun terjadi di dalam masyarakat Lembak di Tahura. Karena di Tahura ini terdapat penduduk Jawa yang tempat tinggal mereka berdampingan dengan penduduk asli Lembak, yang mengakibatkan mereka dapat menguasai bahasa Lembak. Komunikasi dengan menggunakan bahasa Jawa dapat dilihat pada penjelasan berikut.

Setting C terjadi di rumah bapak Tugino (CA)seorang buruh tani yang berusia 40 tahun dengan pendidikan terakhir SMP, yang sedang mengadakan acara aqiqah anaknya. Percakapan terjadi sekitar pukul 11.00 WIB. Dengan partisipan yakni bapak Dedi dan teman lamanya yakni bapak Kaswolo (CB) yang berusia 37tahun seorang honorer dengan pendidikan terakhir SMP. keduanya sama - sama penutur asli bahasa Jawa. Topik pembicaraan yakni tentang "kesehatan bapak Wiji".

CA : Wəs suwə tekonə? Dəwə opo karo bojomu?

( sudah lama datangnya? Sendiri atau sama istri?)

CB : Lumayan suwə, dəwəan waə. Bojoku lagi lungo nəng gonə ponaan səng bar nglairakə ndək bəngi. Piyə Mas, sehatkan?

( Lumayan lama, sendiri saja. Istri lagi pergi ke rumah keponakan yang melahirkan malam tadi. Bagaimana Mas, sehatkan?)

CA : Iyo, səhat waə. Kə koyone setitik kuru, loro opo?

( Iya. Sehat saja. Kamu seperti sedikit kurus.sakit apa ?)

CB : Wulan wingi kulo mlebu rumah sakit, meh rong minggu Mas, neng omah sakit Bhayangkara.

( Bulan kemarin saya masuk rumah sakit hampir dua minggu Mas, di rumah sakit Bhayangkara ).

CA : Aku ora ngerti. Nək ngerti aku nələi. Loro opo?

( Saya tidak tahu. Kalau tahu saya jenguk. Sakit apa?)

CB : Diabetes sama paru - paru Mas. Saiki wae urung sehat tenan.

( Diabetes sam paru - paru Mas. Sekarang saja masih belum sehat betul).

CA : Iyo ketok ko raimu, wəs berobat nəng əndi waə?

( Iya kelihatan dari mukanya. Sudah berobat kemana saja?)

CB : Wəs akəh Mas. Nəng omah sakit M.Yunus, obat jalan, səng terakhir nəng 
omah sakit Bhayangkara.

(Sudah banyak Mas. Di rawat di rumah sakit M.Yunus, obat jalan, terakhir di rumah sakit Bhayangkara).

Percakapan di atas, merupakan percakapan yang menggunakan bahasa Jawa. Situasi pada saat terjadinya komunikasi yakni situasi nonformal yakni di tempat salah satu warga yang mengadakan hajatan. Di dalam komunikasi di atas, tidak terdapat bahasa lain saat terjadinya komunikasi, yang ada hanya bahasa Jawa. Karena partisipan yakni antara penutur dan lawan tutur memang merupakan penutur bahasa Jawa yang berdomisili di daerah Tahura.

Selain itu terdapat juga bahasa Melayu Bengkulu yang digunakan masyarakat untuk berkomunikasi. Perhatikan contoh berikut ini:

DB : Banyak orang rumah ko buək kuə?

( Banyak orang rumah ini membuatk kue?)

DA : Caknyo idak pulo, yuk. Karno Cuma duo hari kemaren tubo Tina buək kuə kemaren.

( Sepertinya tidak juga, yuk. Karena kemarin Cuma dua hari rombongan Tina Membuat kuenya).

DB : Ayuk nanyo samo Eti jugo Cuma duo hari buək kuənyo. Eti la yang mbantu Tina buek kue. Cuma bolu koja, bolu cake, trus samo glamai. Udem tu tubo tu buek kue- kue untuk di toples tu la.

( Ayuk bertanya sama Eti juga Cuma dua hari membuat kuenya. Eti yang

Membantu Tina membuat Kue. Cuma bolu koja, cake, terus sama dodol.

Sesudah itu, mereka membuat kue - kue untuk di toples).

DA : Ambo təngok jugo Cuma dikit memang kuənyo, yuk, Idak banyak

Macamnyo. Ayuk jam berapo ke siko?

(Saya lihat juga Cuma sedikit memang kuenya, yuk, Tidak banyak macamnya. Ayuk jam berapa ke sini?)

DB : Jam delapan ayuk ke siko. Ayuk sampai tadi, lagi bersihkan ayam, baru udəm Motong ayam.

( Jam delapan ayuk ke sini. Ayuk sampai tadi, lagi membersihkan ayam, baru 
sudah memotong ayam)

Komunikasi dengan bahasa Melayu Bengkulu ini terjadi di rumah salah seorang warga yang mengadakan hajatan yaitu rumah bapak Yakunil yang akan mengadakan resepsi pernikahan anaknya. Percakapan terjadi sekitar pukul 13.00 WIB, dengan partisipan yaitu antara Elvi (DA) yang berusia 31 tahun, seorang ibu rumah tangga yang pendidikan akhirnya SMP, dan ibu Fitri (DB) yang berusia 38 tahun seorang ibu rumah tangga dengan pendidikan terakhir SMP. Mereka merupakan penutur bahasa Melayu Bengkulu yang berdomisili di daerah Tahura, adapun topik pembicaraan mereka yakni mengenai"kue".

Percakapan tersebut, merupakan percakapan yang menggunakan bahasa Melayu Bengkulu. Situasi pada saat terjadinya komunikasi yakni situasi nonformal yakni di tempat salah satu warga yang mengadakan hajatan. Di dalam komunikasi di atas, tidak terdapat bahasa lain saat terjadinya komunikasi, yang ada hanya bahasa Melayu Bengkulu. Karena partisipan yakni antara penutur dan lawan tutur memang merupakan penutur bahasa Melayu Bengkulu yang berdomisili di daerah Tahura.

\section{Penggunaan bahasa Lembak dalam komunikasi sehari - hari masyarakat Lembak}

Bahasa Lembak merupakan salah satu bahasa yang digunakan oleh masyarakat Lembak di Tahura untuk berkomunikasi. Perhatikan contoh berikut ini:

EA : Adə nota bayo pajak tanah samə umah ngən En, 500 ribu.

(Ada nota bayar pajak tanah sama umah dengan En, 500 ribu).

EB : Pajak tu berapə? tanah berapə, umah berapə?

(Pajak itu berapa? Tanah berapa? Rumah berapa?).

EA : Seratus limə puluh rumah

(Seratus lima puluhan rumah).

EB : Col mukin umah sapai seratus limə Puluh. ku jingok rumah Mak Uci, Mak Mael rəkapan ngən Dang Ujang tu cuma semilan ribu.coal adə nyə nyapai ratusan.

(Tidak mungkin sampai seratus lima puluhan. Saya melihat yang rumah ibu uci, ibu mael, rekapan dengan kakak ujang itu Cuma sembilan ribu. Tidak ada sampai ratusan).

EC : Nah, ngapə yang kitə beso nian - nian. Cubə tanyə ngapə yang wang 
kecik yang kitə beso nian - nian, padahal wang tu umah samə tanah nye samə ngən kitə.

(Nah, mengapa yang kita besar sekali. Coba tanya mengapa yang orang kecil yang besar sekai, padahal rumah orang itu sama tanahnya sama seperti kita).

EB : Dilək ku nanyə, ngapə nye sapai cak tu. Setau ku bayo pajak tu pertaun, tapi yang wang dak sapai cak kitə beso nian.

(Nanti saya tanya, mengapa sampai seperti itu. Setahu saya bayar pajak itu pertahun, yang orang orang tidak sampai seperti kita besar sekali).

EA : Au. Bayar pajak tu pertaun.

( Iya. Bayar pajak pertahun).

EB : Kini carək bayo pajak tu cəkmanə? Apə punyə tanah apə col,apə harus adə sertifikat apə col. Setau ku bayar pajak tu arus ade sertifikat tanah.

(Sekarang sistim bayar pajak itu bagaimana apa punya tanah apa tidak, apa harus ada sertifikat apa tidak. Setahu saya bayar pajak itu harus adasertifikat tanah).

EA : Col arus adə sertifikat tana, kalu tedaftar sebagai penduduk arus bayo pajak.

(Tidak harus ada sertifikat tanah, kalau terdaftar sebagai penduduk harus bayar pajak)

EB : Cubək la di tagih apə nyuk sebelumnyə, kitə ngapə sapai limə ratusan, ikak jakmanə nyucuk ə sapai se beso itu. (Cobalah di tagih apa di kasih tahu sebelumnya, kenapa kita sampai lima ratusan, darimana dapatnya sampai sebesar itu)

Percakapan pada Setting E tersebut menggunakan satu bahasa, yakni bahasa Lembak. komunikasi terjadi pada malam hari pukul 19.05 WIB, dengan situasi santai di rumah bapak 
Muslim (EA), ia seorang petani sawit yang berusia 57 tahun dengan pendidikan terakhir SD. Komunikasi terjadi antara bapak Muslim dengan anaknya yang bernama Dodi (EB) yang berusia 26 tahun seorang anggota polri tamatan SMA yang sedang melanjutkan pendidikan di perguruan tinggi. Serta istrinya yang bernama Irmani (EC) yang berusia 55 tahun seorang ibu rumah tangga yangpendidikan terakhir SD. Adapun topik pembicaraan dalam percakapan tersebut yaitu tentang "pajak".

Percakapan di atas menunjukkan adanya SPEAKING dalam komunikasi tersebut. Ini bisa kita lihat bahwa, percakapan tersebut terjadi di rumah bapak Muslim dengan situasi santai, dan juga terdapat partisipan yang memiliki usia, profesi dan tingkat pendidikan yang berbeda. Adapun penutur dalam parcakapan di atas yaitu bapak Muslim, dan lawan tuturnya adalah Dodi dan Irmani. Tujuan dari komunikasi tersebut untuk membahas masalah pembayaran pajak yang tidak sesuai. Salah satu lawan tutur dalam percakapan di atas, yaitu Irmani menggunakan kesempatan bicara dengan nada sedikit tinggi, untuk menanggapi informasi yang diungkapkan oleh Dodi mengenai pajak seorang tetangganya yang lebih murah dibandingkan pajak yang mereka harus bayar.

Dari percakapan pada setting E bisa kita lihat bahwa percakapan tersebut menggunakan bahasa Lembak, tanpa ada campur kode ataupun alih kode ke bahasa lain. Tidak ada faktor yang memungkinkan untuk menggunakan bahasa lain yang mengakibatkan munculnya alih kode dan campur kode dalam percakapan tersebut, faktor itu misalnya, adanya lawan tutur lain yang tidak mengerti bahasa Lembak, sehingga mengharuskan menggunakan bahasa lain untuk berkomunikai dengan lawan tutur tersebut. Dalam percakapan di atas, partisipan yang terlibat dalam komunikasi tersebut merupakan satu keluarga, yang memang latar belakangnya merupakan penduduk asli Lembak yang dalam kesehariannya menggunakan bahasa Lembak sebagai alat komunikasi.

Akibat adanya penggunaaan bahasa lain selain bahasa Lembak dalam komunikasi masyarakat di Tahura, maka muncul komunikasi campur kode dan alih kode antara bahasa Lembak dengan bahasa lain, yakni bahasa Melayu Bengkulu, Rejang dan Jawa. Berikut ini adalah contoh penggunaan bahasa Lembak dalam aktivitas masyarakat Lembak di Tahura, yang dimasuki unsur bahasa Lain.

\section{a. CKTL $<$ UMB}

CKTL < UMB adalah rumusan dari campur kode tuturan Lembak yang dimasuki unsur Melayu Bengkulu. Untuk lebih jelasnya Perhatikan contoh kalimat (1) dan (2) berikut:

1) Waktu nyə ngeyuk suhat ngan ku, col adə nyə ngəcək apə - apə.

(Waktu dia memberikan surat dengan saya, tidak ada dia mengatakan apa-apa).

2) Waktu nyə ngeyuk surзk ngan ku, col adə nyə ngəcək apə - apə. (Setting F: FB 5)

(Waktu dia memberikan surat dengan saya, tidak ada dia mengatakan apa-Apa).

Komunikasi pada setting F terjadi di rumah bapak Anang di desa Tanjung Terdana, Tahura. Percakapan berlangsung sore hari. Sekitar pukul 16.00 WIB dengan topik pembicaraan"surat panggilan orang tua". Partisipan dalam percakapan ini ada dua orang, 
Yaitu bapak Anang (FA) yang merupakan suami dari Sayati (FB). FA adalah seorang petani sawit yang berusia 45 tahun dengan pendidikan terakhir SMA, yang merupakan penutur asli bahasa Lembak dan menguasai bahasa Melayu Bengkulu, dan FB sendiri adalah seorang ibu rumah tangga yang berusia 41 tahun dengan pendidikan terakhir SMA, yang merupakan penutur asli bahasa Melayu Bengkulu yang menguasai bahasa Lembak.

\section{b CKTL $<$ URJ}

CKTL <URJ adalah rumusan dari campur kode tuturan Lembak yang di masuki unsur bahasa Rejang. Masyarakat Lembak juga menggunakan unsur bahasa Rejang dalam tuturan bahasa Lembak yang mereka gunakan. Penggunaan bahasa Lembak yang dimasuki unsur bahasa Rejang ini, mengakibatkan terjadinya campur kode. Perhatikan contoh berikut ini:

5) Jak ncari Reni, adə jingok Reni Dang?

6). Jak ncari Reni, adə kemleah Reni Dang? (H : HA 2)

(Dari mencari Reni, ada melihat Reni Dang?).

Setting $\mathrm{H}$ berlokasi di depan balai desa dalam situasi non formal, sekitar pukul 11.00 WIB, dengan partisispan yakni Fredi (HA) dan Sanar (HB). HA adalah penutur asli bahasa Rejang yang menguasai bahasa Lembak dan Melayu Bengkulu. Ia berusia 18 tahun dengan profesi sebagai petani sawit dan pendidikan terakhirnya SMP, HB adalah seorang supir truk yang berusia 25 tahun dengan pendidikan terakhir SMA, yang merupakan penutur bahasa Lembak yang menguasai bahasa Rejang dan juga Melayu Bengkulu. Adapun topik pembicaraan adalah "kaburnya keponakan dari HA ".

Percakapan pada setting $\mathrm{H}$ menunjukkan bahwa partisipan yang terlibat dalam komunikasi tersebut, memiliki latar belakang usia, pekerjaan dan pendidikan yang berbeda. Penutur dalam percakapan tersebut yaitu HA yang merupakan penutur asli bahasa Rejang, sedangkan lawan tuturnya yaitu HB yang merupakan penutur asli bahasa Lembak. Komunikasi dalam percakapan tersebut, juga menunjukkan adanya aturan yang berlaku dalam berkomunikasi dengan yang lebih tua. Hal ini ditunjukkan dengan adanya kata "Dang" sebagai kata sapaan untuk orang yang lebih tua dalam tuturan tersebut, yang mengandung makna"kakak".

\section{c $\mathbf{C K T L}<\mathbf{U J}$}

CKTL $<$ UJ adalah rumusan dari campur kode tuturan Lembak yang dimasuki unsur bahasa Jawa. Perhatikan contoh kalimat (11) dan (12) berikut:

9). Mas, bukus əsnyə duə. Tapainyə dikit baə.

10). Mas, bukus əsnyə loro. Tapainyə dikit baə. ( setting J : JB 1 )

( Mas, bungkus esnya dua. Tapainya sedikit saja ). 
Kalimat (9) dan kalimat (10) merupakan contoh kalimat Setting J belokasikan di pinggir jalan di depan rumah bapak Yakunil yang sedang mengadakan pesta pernikahan anaknya. Komunikasi terjadi sekitar pukul 13.00 WIB dengan partisipan Suyanto (JA) dan Kunthi (JB). JA adalah seorang penjual es yang berusia 32 tahun dengan pendidikan terakhir SMA, yang merupakan penutur asli bahasa Jawa namun, mengerti bahasa Lembak karena ia berdomisili di daerah Tahura. Sedangkan JB adalah seorang ibu rumah tangga yang berusia 40 tahun dengan pendidikan terakhir SMA. Ia adalah penutur bahasa Lembak yang menguasai bahasa Jawa.

Tuturan dalam K9 merupakan tuturan bahasa Lembak murni tanpa adanya percampuran unsur bahasa lain. Kalimat 10 menunjukkan adanya campur kode antara bahasa Lembak dan Jawa. Ini terbukti dengan adanya kataloro yang mengandung arti " dua". Masuknya bahasa lain yakni bahasa Jawa ke dalam bahasa Lembak pada saat komunikasi, mengakibatkan terjadinya peristiwa campur kode.

Komunikasi pada tuturan di atas, terdapat kata sapaan Mas yang digunakan oleh penutur untuk menyapa penjual es. Jadi, dalam tuturan tersebut terdapat norma kesopanan antara yang lebih muda terhadap yang tua.

Terjadinya campur kode pada setting J K10 disebabkan karena adanya faktor penutur, yang ingin lawan tuturnya mengerti maksud dari apa yang ia tuturkan. Karena lawan tuturnya penutur asli bahasa Jawa, maka penutur menggunakan kosa kata Jawa untuk memperjelas tuturannya.

\section{d CKTL $<$ UMB dan UR}

Selain campur kode dengan dua partisipan dan satu unsur bahasa yang masuk dalam bahasa tuturan seperti beberapa contoh kalimat di atas, ada juga campur kode yang dimasuki dua unsur bahasa yang masuk dalam bahasa tuturan. Perhatikan contoh berikut ini.

11) Alangkah segə ngusir burung ikak. Tiap arai tamah banyak baə nyə datang makan padi, lamə - lamə abis padi ikak

12) Alangkah payah ngusir burung ikak. Tiap arai tamah deu baə nyə datang makan padi, lamə - lamə abis padi ikak ( seting K: KA 2)

(Alangkah payah mengusir burung ini. Tiap hari tambah banyak saja dia datang makan padi, lama - lama abis padi ini).

Setting K pada kalimat 11 dan 12 berlokasikan di sawah milik bapak Idham di desa Dusun Baru I, Tahura. Percakapan berlangsung siang hari, pukul $13.00 \mathrm{WIB}$, dengan topik pembicaraan"padi yang dimakan burung" . percakapan ini dilakukan oleh 3 orang, yaitu Firdaus (KA), Idham (KB), Nurjana (KC). KA adalah orang bekerja menolong bapak Idham di sawah yang merupakan penutur asli bahasa Lembak yang menguasai bahasa Melayu bengkulu dan bahasa Rejang. Ia berusia 49 tahun dengan pendidikan terakhir SD. KB adalah pemilik sawah yang merupakan penutur bahasa Melayu Bengkulu dan menguasai bahasa Lembak yang berusia 53 tahun dengan pendidikan terakhir SMA. KC adalah istri pemilik 
sawah yang juga penutur bahasa Melayu Bengkulu yang menguasai bahasa Lembak dan Rejang. Ia seorang ibu rumah tangga yang berusia 42 tahun dengan pendidikan terakhir SMP.

Pada Setting K K12, merupakan peristiwa campur kode terjadi karena faktor peranan bahasa, artinya penutur ingin memperjelaskan tuturan yang ia sampaikan kepada lawan tuturnya, karena lawan tuturnya terdiri dari berbagai suku dan bahasa. Kata payah dalam kalimat di atas merupakan bahasa Melayu Bengkulu, yang bila dalam bahasa Lembaknya adalah sege. Sedangkan kata deu yang merupakan unsur bahasa Rejang yang mengandung makna banyak, bila disubstitusikan dengan unsur bahasa Lembak maka akan tetap gramatikal. Kedua unsur yang masuk ke dalam tuturan bahasa Lembak tersebut bila disubstitusikan dengan kosakata bahasa Lembak, akan menajadi tuturan dalam bahasa Lembak seperti pada K11.

\section{e AKTL >BMB}

AKTL >BMB adalah rumusan dari alih kode tuturan bahasa Lembak beralih ke tuturan bahasa Melayu Bengkulu. Perhatikan contoh berikut ini:

19) Alangkah malu kitə au pak, samə guru - guru Arief. Guru - guruə banyak kenal pulə, apə katə gurunyə dilək?

20) Alangkah malu kito yo, Pak samo guru - guru Arief. Guru - guruə banyak kenal pulə, apə katə gurunyə dilək? ( Setting F : FB 11)

( Alangkah malu kita, Pak sama guru - guru Dayat. Guru -gurunya banyak kenal pula, apa nanti kata gurunya?)

Komunikasi pada setting F dalam situasi nonformal terjadi di rumah bapak Anang di desa Tanjung Terdana, Tahura. Percakapan berlangsung sore hari. Sekitar pukul 16.00 WIB dengan topik pembicaraan"surat panggilan orang tua". Partisipan dalam percakapan ini ada dua orang, Yaitu bapak Anang (FA) yang merupakan suami dari Sayati (FB). FA adalah seorang petani sawit yang berusia 45 tahun dengan pendidikan terakhir SMA, yang merupakan penutur asli bahasa Lembak dan menguasai bahasa Melayu Bengkulu, dan FB sendiri adalah seorang ibu rumah tangga yang berusia 41 tahun dengan pendidikan terakhir SMA, yang merupakan penutur asli bahasa Melayu Bengkulu yang menguasai bahasa Lembak.

Peristiwa alih kode di atas terjadi karena faktor suasana pembicaraan, karena pada saat percakapan tersebut, mitra tutur juga terkadang beralih kode ke bahasa Melayu Bengkulu, sehingga penutur juga terbawa untuk beralih kode dari bahasa Lembak ke bahasa Melayu Bengkulu. Alih kode dalam tuturan tersebut juga menunjukkan norma kesopanan antara seorang istri dengan suaminya. Kata sapaan $P a k$ digunakan penutur untuk panggilan suaminya dalam tuturan lisan saat komunikasi berlangsung.

Selain Alih kode, pada komunikasi di daerah sekitar Tahura juga mengalami Campur Kode. Berikut ini merupakan contoh dari Campur Kode: 
.a CKTMB $<$ UL

CKTMB < UL adalah rumusan dari campur kode tuturan Melayu Bengkulu yang dimasuki unsur bahasa Lembak. Perhatikan contoh berikut ini:

25) Kato datuk dulu, sanak keluargo ko kalau dak di cari dak kan ketemu, yo dak tu Pakwo?

26) Kato datuk dulu, sanak keluargə ko kalau dak di cari dak kan ketemu, yo dak tu Pakwo?

(Setting O : OA 11)

(Kata kakek dulu, sanak famili ini kalau tidak dicari tidak akan ketemu, iya tidak Pakwo?).

Setting O berlokasi di rumah bapak Muslim sekitar pukul 17.00WIB. Komunikasi terjadi antara dua partisipan yaitu bapak Bana (OA) dan Muslim (OB). OA adalah penutur asli bahasa Melayu Bengkulu yang menguasai bahasa Lembak dan Rejang yang merupakan tamu. Ia seorang petani sawit berusia 22 tahun dengan pendidikan terakhir SMA. Sedangkan OB adalah seorang petani sawit yang berusia 57 tahun. Ia penutur asli bahasa Lembak yang menguasai bahasa Melayu Bengkulu. Topik pembicaraan adalah tentang "silsilah keluarga".

Setting O kalimat 25 merupakan tuturan bahasa Melayu Bengkulu asli tanpa adanya percampuran unsur bahasa lain. Sedangkan 26menunjukkan adanya campur kode antara bahasa Melayu Bengkulu dan bahasa Lembak. Masuknya bahasa Lembak ke dalam bahasa Melayu Bengkulu ditandai dengan adanya kata keluarge pada K26yang mengandung makna keluarga.

Tuturan pada setting $\mathrm{O}$ menunjukkan adanya tempat terjadinya komunikasi, yakni di rumah. Percakapan berlangsung dengan tujuan untuk mengetahui tali kekeluargaan dari kerabat si penutur. Di dalam percakapan tersebut, terdapat juga norma atau aturan yang berlaku. Hal ini, ditunjukkan dengan adanya kata sapaan untuk orang yang lebih tua dari orang tua si penutur. Kata sapaan dalam kalimat di atas, yakni kata Pakwo.

Kata keluarge dalam bahasa Lembak tersebut dapat berdistribusi dengan kata keluargo dalam bahasa Melayu Bengkulu, untuk membuktikan bahwa tuturan K26 merupakan tuturan campur kode antara bahasa Melayu Bengkulu dengan bahasa Lembak maka, unsur bahasa Lembak yaitu keluarge disubstitusikan dengan kata keluargo dalam bahasa Melayu Bengkulu. Tuturan dengan menggunakan Kata keluarge yang masuk dalam bahasa Melayu Bengkulu tersebut tetap gramatikal.

\section{b $\mathbf{C K T M B}<\mathbf{U J}$}

CKTMB < UJ adalah rumusan dari campur kode tuturan Melayu Bengkulu yang dimasuki unsur bahasa Jawa. Perhatikan contoh berikut ini:

27). ........Idak masuk tu yuk. Cubo cari di toko Murah Meriah tu na yuk.banyak bajunyo yang əlok siapo tahu masuk samo roknyo. 
28).......Orak masuk tu yuk. Cubo cari di toko Murah Meriah tu na yuk.banyak bajunyo yang əlok siapo tahu masuk samo roknyo.( setting P : PA 7)

(.......Tidak masuk itu yuk. Coba cari di toko Murah Meriah itu yuk, banyak yang bagus bajunya siap tahu masuk dengan roknya ).

Setting P berlokasi di halaman PAUD di desa Tanjung Terdana sekitar pukul 10.00 WIB dengan partisipan yakni Linsi (PA) dan Sri (PB). OA adalah seorang ibu yang memiliki warung manisan yang berusia 30 tahun dengan pendidikan terakhir SMA. Ia adalah penutur bahasa Melayu Bengkulu dan menguasai bahasa Jawa dan bahasa Lembak. Sedangkan PB seorang ibu rumah tangga yang berusia 27 tahun dengan pendidikan terakhir SMP. PB adalah penutur asli bahasa Jawa yang menguasai bahasa Melayu Bengkulu . Topik pembicaraan antara keduanya yaitu mengenai "baju untuk lomba anak - anak mereka "

Tuturan pada setting $\mathrm{P}$ tersebut terjadi di halaman PAUD. Berdasarkan penelitian, penutur dan lawan tutur dalam percakapan adalah sahabat karib yang sudah lama berteman. Sewaktu percakapan berlangsung keduanya terlihat sangat akrab, dan tuturan dengan nada sedikit menyindir pun terlihat dalam tuturan K28. Tuturan pada setting $\mathrm{P}$ ini juga menunjukkan aturan yang berlaku pada saat berlangsungnnya percakapan. Hal ini, ditunjukkan dengan kata $Y u k$, sebagai sapaan untuk seorang perempuan yang lebih tua. Tujuan akhir dari percakapan ini adalah memberikan informasi mengenai baju yang cocok untuk anak dari LB.

Kalimat 28 pada setting $\mathrm{P}$ juga menunjukkan adanya campur kode. Campur kode tersebut ditunjukkan dengan adanya kata orak, yang mengandung makna tidak. Jika didalam bahasa Melayu Bengkulunya adalahidak yang maknanya juga tidak. Bila unsur bahasa Jawa tersebut di substitusikan ke dalam bahasa Lembak, maka kalimatnya menjadi seperti K27.

Terjadinya campur kode dalam komunikasi di atas disebabkan karena peranan penutur, yang ingin maksud pembicaraan yang ia sampaikan dapat di pahami oleh lawan tuturnya yang merupakan penutur asli bahasa Jawa.

\section{PENUTUP}

Berdasarkan penelitian dan pembahasan tentang penggunaan bahasa dalam aktivitas sehari - hari masyarakat Lembak di Tahura, maka dapat disimpulkan sebagai berikut:

Di dalam masyarakat Lembak di Tahura, terdapat beberapa bahasa yang digunakan sebagai sarana komunikasi. Adapun bahasa - bahasa tersebut antara lain, bahasa Lembak, Rejang, Melayu Bengkulu dan Jawa. Penggunaan keempat bahasa tersebut sesuai dengan konteks, dan partisipan. Konteks dalam penelitian ini adalah di rumah, warung, sawah, sekolah, kebun, di pinggir jalan, dan di tempat salah satu warga yang hajatan. Dengan partisipan yang usianya muda yakni 17 tahun sampai dengan yang tua yang berusia 58 tahun.

Tingkat pendidikan partisipan dalam penelitian ini juga berbeda - beda, mulai dari yang tidak sekolah, SD, SMP. SMA, dan perguruan tinggi. Adapun pekerjaan partisipan yang terlibat dalam komunikasi juga berbeda - beda, ada yang ibu rumah tangga, petani sawah, petani karet, petani sawit, kuli bangunan, supir truk, pelajar, anggota polri, mahasiswa, dan 
peternak ayam. Dengan adanya perbedaan usia, pendidikan, pekerjaan dan konteks percakapan maka, penutur dan lawan tutur menggunakan lebih dari satu bahasa. Akibatnya, tuturan dalam komunikasi yang berlangsung terjadi campur kode dan alih kode.

Adapun faktor - faktor yang mempengaruhi terjadinya campur kode didalam masyarakat Lembak di tahura, antara lain:

a. Adanya kemiripan bentuk bahasa

b. Kehadiran mitra tutur bahasa lain

c. Peranan penutur

Sedangkan faktor yang mempengaruhi terjadinya alih kode didalam masyarakat Lembak di Tahura, antara lain:
a. Membangkitkan rasa humor.
b. Untuk sekedar bergengsi
c. Kehadiran mitra tutur

Sebaiknya kita tidak melakukan campur kode pada saat berkomunikasi. Karena dengan mencampurkan kode bahasa satu dengan bahasa lain, lama - kelamaan akan mengakibatkan suatu bahasa tersebut kehilangan satu kode bahasa mereka, yang telah dikenal masyarakat sebagai kode bahasa tertentu.

Maka, untuk menghindari terjadinya pelanggaran sikap berbahasa campur kode, kita harus membiasakan diri untuk tidak mencampurkan kode bahasa satu dengan kode bahasa lain ke bahasa tuturan yang kita gunakan.

\section{DAFTAR PUSTAKA}

Adiel. 2009. Alih Kode, Campur Kode, Interferensi.www. http:/ilmu linguistiksosiolinguistik.co.id / (diakses 3 Januari 2011).

Chaer, Abdul, dkk.2004. Sosiolinguistik Perkembangan Awal, Jakarta:PT. Rineka Cipta

Djajasudarma, T. Fatimah. 2006. Metode Linguistik Ancangan Metode Penelitian dan Kajian, Bandung: Refika Aditama. 1984. Pemilihan bahasa dalam komunikasi. Jakarta: PT. Rineka Cipta.

Fitri Mediana Desi.2002.Alih Kode dan Campur Kode dalam Bahasa Lembak, Bengkulu: Universitas Bengkulu.

Furchan, Arief.1991. Metode Penelitian Kualitatif, Bandung: Bineka Cipta.

Grosjean.1982. Pemilihan bahasa sesuai konteks. Jakarta: Bineka Cipta.

Ibrahim, syukur. 1993. Kapita Selekta Sosiolinguistik. Surabaya: Usaha Nasional.

Ibrahim, syukur.1979. Prinsip dan Metode Linguistik Historis, Surabaya: Usaha Nasional. 
J.W.M. Verhaar. 1996. Asas - Asas Linguistik Umum. Yogyakarta: Gadjah Mada Univeristy Press.

Minarti Eli. 2004. Bilingualisme dalam Komunikasi Lisan Masyarakat Lembak di Kecamatan Kota Padang Kabupaten Rejang Lebong, Bengkulu: Universitas Bengkulu.

Moleong, Lexy J. 1988. Metode Penelitian Kualitatif, Bandung: PT. Remaja Rosda Karya.

Nababan, PWJ.1991 Sosiolinguistik Suatu Pengantar, Jakarta: Gramedia Pustaka Utama.

Pusat Bahasa. 2009. Pedoman Penelitian Sosiolinguistik, Jakarta: Pusat Bahasa

Sadiki, Malik. 2008. Konteks situasi komunikasi..www. http://jurnal- linguistik.com (diakses 10 Januaru 2011).

Sandra, Lita. 2010. Sosiolinguistik di Masyarakat.www.http://Artikel Sosio-Linguistik, com/(diakses 3 Januari 2011).

Suwito, 1983. Artikel Sosiolinguistik. www. Http:// Artikel - suwito - sosio, co.id/( di akses( 7 januari 2011)

Yummi, Yulius. 2010. Artikel Sosiolinguistik.www.http//sosiolinguitik.co.id, (diakses 3 Januari 2011). 